\title{
A INTERTEXTUALIDADE COMO ENGENHO: O BRASIL DE DRUMMOND NA BRAXÍLIA DE NICOLAS BEHR
}

\author{
Wilberth SALGUEIRO (UFES/CNPq) ${ }^{1}$ \\ rio do mistério \\ que seria de mim \\ se me levassem a sério? \\ Paulo Leminski (1987, p. 116)
}

No dia em que descobrirem minha poesia vão acabar com ela. Mas eu arraso antes. Digo que éfast-food, poesia fácil, eu mesmo me arraso. É uma defesa, um escudo. Nicolas Behr (2004, p. 47)

\begin{abstract}
RESUMO: entende-se, comumente, que o recurso da intertextualidade se associa a categorias como influência e subversão, gosto e erudição. Laurent Jenny diz, em "A estratégia da forma" (1979), que a intertextualidade é uma "máquina perturbadora", que solicita do sentido incessantes deslocamentos. Theodor Adorno, por sua vez, num dos aforismos de Minima moralia (1951), afirma que toda obra de arte, porque sempre cotejada com seus pares, quer "levar a morte a todas as outras" ("De gustibus est disputandum"). Conjugando ambas as reflexões, de Jenny e de Adorno, procurarei mostrar, através da análise breve de três poemas de Laranja seleta (2007), de Nicolas Behr, como este poeta se apropriou intertextualmente de poemas de Drummond para pensar a história contemporânea do Brasil: contra a sombra da desesperança, a resistência do humor (seja em versão sarcástica, retórica ou merencória).
\end{abstract}

PALAVRAS-CHAVE: Nicolas Behr; Carlos Drummond de Andrade; Intertextualidade; Laurent Jenny; Theodor Adorno.

ABSTRACT: It is normally understood that intertextuality is associated with categories such as influence and subversion, taste and erudition. Laurent Jenny says, in "The strategy of form" (1979), that intertextuality is a "disturbing machine", which demands incessant shifts from meaning. Theodor Adorno, in an aphorism from Minima moralia (1951), states that every work of art, because they are always confronted with their pairs, wants "to cause the death of all the others" ("De gustibus est disputandum"). Conjugating both reflections, Jenny's and Adorno's, I want to show, through the analyses of three poems from Laranja seleta (2007), by Nicholas Behr, the way the poet intertextually uses poems by Drummond to think about the contemporary history of Brazil: against the shadow of despair, the resistance of humor (may it be in a sarcastic, rhetoric, or melancholic version).

KEYWORDS: Nicolas Behr; Carlos Drummond de Andrade; Intertextuality; Laurent Jenny; Theodor Adorno. 
Em 2007, Nicolas Behr - poeta cuiabano, radicado em Brasília - lançou a antologia Laranja seleta, com poemas produzidos desde o longínquo ano de 1977.

Indicado aos prestigiosos prêmios Jabuti e Portugal Telecom, o livro trouxe a um público maior a figura singular de Behr, verdadeiro militante do verso e do verde, na lida há tempos com plantas e páginas, flores e congêneres. Leitores antenados em poesia brasileira devem ter a devida dimensão do nome do escritor em nosso panorama poético, ao lado de outros históricos e canônicos marginais como Glauco Mattoso, Roberto Piva, Leila Míccolis, Tião Nunes, Chacal e Waldo Motta, para listar alguns poucos.

Pelo fato mesmo de ser uma antologia tão abrangente (dezenas - sic - de livros de 1977 a 2007) e de contar com escolha do próprio autor, sua representatividade é inconteste: as quase duas centenas de poemas de Laranja seleta dão uma idéia bem boa da trajetória poética de Behr, dono de uma biografia que inclui prisão e processo por parte do DOPS, em 1978, acusado de "porte de material pornográfico" e "também por suas atividades políticas no movimento estudantil" 2 . Data de então, de 15 de novembro de 1978, uma preciosa carta de solidariedade de Drummond, que aí comenta: "vejo como pode ser perigoso para o cidadão ter em seu poder 'livretos de cunho pornográphico', cuja classificação fica dependendo do senso crítico de autoridades policiais. A ameaça pode atingir quem tenha em casa a Bíblia em fascículos, ou um drama de Shakespeare em quadrinhos. O que não impede que nas bancas de jornais... Sem comentários" (BEHR, 2005, p. 112). A verve do poeta se faz ver na referência nada simpática à censura das "autoridades policiais", nos exemplos inusitados ("Bíblia em fascículos", "Shakespeare em quadrinhos") e mesmo na indicação elíptica do paradoxo do argumento repressor: se o livro de Behr foi censurado por pornográfico, o que dizer do que se via, e se vê, nas bancas de jornais? O comentário, ferino, se fez.

Em Laranja seleta - portanto, na obra de Behr - um estilema que se quer visível é a intertextualidade. Lá, abundam alusões a poemas e poetas da estirpe do citado Shakespeare a Castro Alves, de Caetano Veloso a Torquato Neto, de Mário de Andrade a Manuel Bandeira, de Glauco Mattoso a Adélia Prado, mas, sobretudo, chovem 
referências ao solidário missivista itabirano. Para além de ser um traço marcadamente geracional, pergunta-se: por que a freqüência do recurso à intertextualidade? E Drummond, exatamente ele, Drummond - por quê?

O volume 27 da Poétique dedicou-se ao estudo da intertextualidade. $\mathrm{O}$ artigo de abertura, "A estratégia da forma", de Laurent Jenny (1979), faz um apanhado relevante da questão, afirmando, de saída, que, "fora da intertextualidade, a obra literária seria muito simplesmente incompreensível" (p. 5), considerando o termo em sentido deveras lato, como o fez igualmente a búlgara Julia Kristeva ao cunhar o conceito em frase que se celebrizou: "qualquer texto se constrói como um mosaico de citações e é absorção e transformação dum outro texto" (1974, p. 64). Se, por hipótese, um texto "esconde" o tal mosaico, esta postura mesma manifestaria o seu estatuto. É como se, quanto a isto, não houvesse saída: citar ou não, de forma mais ou menos explícita, via imitação, paródia, montagem ou plágio, pouco importa: os intertextos estão em toda parte, formam uma teia absolutamente inescapável. O teórico francês trabalha tais questões com farta exemplificação, a partir de William Burroughs, Raymond Queneau, James Joyce, Petrônio, Claude Simon e, mais que todos, Lautréamont.

Às vezes, o embate se exterioriza de tal modo que a intertextualidade se torna uma verdadeira máquina de guerra: é o que propõe Harold Bloom em seu A angústia da influência(1991), publicado originalmente em 1973. Aqui, o crítico americano ergue uma teoria da poesia baseada numa sólida rede interativa de poetas fortes e pretendentes $a$ - ambas as categorias de acordo, e tão-somente, com seu juízo avaliativo. Sem meias palavras, acentua que seu único interesse são "os poetas fortes, grandes figuras com persistência para combater seus precursores fortes até a morte. Talentos mais fracos são presa de idealizações: a imaginação capaz se apropria de tudo para si” (p. 33). Bloom não esconde que seu cânone é resultado de um "gosto etnocêntrico", praticamente ignorando as literaturas ditas periféricas. Na apresentação do livro, Arthur Nestrovski retoma a referência ao texto "Kafka e seus precursores", de Jorge Luís Borges, onde o escritor argentino acentua que "todo escritor cria seus precursores. Sua obra modifica nossa concepção do passado, como haverá de modificar o futuro” (p. 12). Assim, a potência da obra kafkiana transforma nossa leitura de obras distantes no tempo e no 
espaço, adjetivando-as — mal comparando, é como se disséssemos que a visão corrosiva, satírica e metapoética de Gregório de Matos fosse oswaldiana.

O efebo poeta deve - se quiser alçar um grau elevado - desler o poeta forte, contrapondo-se a ele. Percebe-se a fundamental presença das concepções edipianas de Freud $\boldsymbol{e m B l o o m}$, além da igualmente confessada sombra de Nietzsche, sobretudo quando lança mão de definições contundentes do filósofo alemão, que atribui ao sentir-poeta um misto exclusivo de consciência da inutilidade do ser e do mundo, donde a equivalência da dissipação do sujeito e da humanidade. Salienta-se, em Bloom, o desejo dos poetas: imitar, homenagear, reverenciar; mas, também, superar, desler, diferenciar. A citação legitima, sim, a hierarquia; mas, de novo com Nietzsche, há que se saber os inimigos: o que não me mata me fortalece.

Para Laurent Jenny "o olhar intertextual é sempre um olhar crítico" (p. 10), em que têm lugar complexas operações de assimilação e transformação, através de elipses, paronomásias, amplificações, hipérboles, interversões de variada ordem etc. Um ponto decisivo reside em detectar o grau da intertextualidade, desde uma sutil reminiscência a um desabusado plágio, de um emaranhado jogo anagramático de timbre saussureano a uma citação espetacularizada de um cânone. De um jeito ou de outro, a intertextualidade é uma "máquina perturbadora" (p. 45), com “vocação crítica, lúdica e exploradora" (p. 49), que solicita do sentido incessantes deslocamentos. Por fim, o jogo intertextual reacende o debate em torno do lugar do sentido e da figura do sujeito, amalgamados sob lavas de discursos alheios.

Apesar de reconhecer o "suporte ideológico confesso" (p. 49) do uso intertextual, o artigo de Jenny é lacunar quanto às intrínsecas relações entre intertextualidade e história: que interesses ideológicos (confessos ou não) são mobilizados quando um autor se apropria de outro? Vale dizer, quando um texto se apropria de outro, e esta apropriação é sempre crítica (porque julga o texto anterior), o que é que se quer transformar na história que o texto apropriado representa? Particularizando a pergunta, por que tantos poemas de Drummond (exatamente ele, Drummond) são tomados, vampirizados por Nicolas Behr? Certamente, a presença de Drummond aí não é inconsciente nem aleatória. Seja um desrecalque, um ato lúdico, um 
gesto encomiástico - um motivo há em tudo o que se cita, em tudo o que se ingere, em tudo o que se regurgita. $\mathrm{O}$ excesso, de algum modo, há de transbordar, diferido noutra matéria.

Já em 1979, em Põe sia nisso!, Behr recupera um poema clássico do livro inaugural de Drummond, Alguma poesia, de 1930. Cotejemo-los:

"Política literária"

A Manuel Bandeira

O poeta municipal discute com o poeta estadual qual deles é capaz de bater o poeta federal.

Enquanto isso o poeta federal tira ouro do nariz.
"Política literária"

(com licença, carlos)

o poeta da asa norte

discute com o poeta

da asa sul

pra ver qual deles

é capaz de bater

o poeta do plano piloto

(DRUMMOND, 2006, p. 15) enquanto isso um poeta

de uma cidade-satélite qualquer

tira a lama

do sapato

(BEHR, 2007, p. 59)

Desde o título, mantido ipsis litteris, e o "agradecimento", entrega-se a fonte: trata-se de um poema do poeta brasileiro $\underline{3}$. A irreverência do modernista ironiza a emulação poética, a partir de uma cômica hierarquia entre poetas: enquanto os dois subalternos - o municipal e o estadual - discutem, o poeta "superior", o federal, qual um Midas tupiniquim, transforma em bem o lixo, em ouro o muco, em valor a meleca. Funcionário público desde 1929, Drummond denuncia disputas e vaidades no ígneo mundo das poéticas, à maneira das quadrilhas políticas. Sofrerá, ao longo de décadas, o estigma de ser funcionário público e, à revelia ou não, contribuir para o fortalecimento por exemplo, sendo secretário de Capanema - do governo getulista 4 . O evidente tom jocoso, o aspecto metapoético, os paralelismos e as fortes aliterações decerto contribuíram para o poeta ter alinhado o poema entre os "exercícios lúdicos" de "Uma, duas argolinhas" de sua antologia de 1962 (e não, como se poderia crer, na seção "Na 
praça de convites", em que figuram poemas que trazem "o choque social") (ANDRADE, 2009).

À primeira vista, o caráter nacional do poema de Drummond dá lugar a uma problemática local no poema de Behr. Aqui, os dois subalternos se travestem de "o poeta da asa sul" e "o poeta da asa norte" e o poeta superior é o "do plano piloto". Fora do panteão, um quarto personagem aparece, para desafinar o coro dos contentes: é "um poeta de uma cidade-satélite qualquer". Enquanto os três poetas da capital se ocupam de questões estéticas, o poeta periférico se vê às voltas com questões aparentemente triviais: tirar a lama do sapato. Mas é aí mesmo o epicentro do problema: o bem-estar, o progresso, a modernidade, o asfalto não chegam para todos. A grande maioria tem de se virar e conviver com o desconforto, a estagnação, o atraso, a treva - a lama. Uns são capitais; outros, satélites. A força ideológica do poema de Behr reside em trazer para a cena poética, por meio do recurso à intertextualidade, uma situação marginal que, sem deixar de ser específica, transcende o contexto regional que indicia. Repare-se, ademais, que sutilmente ecoa na paródia de Behr a lembrança do poema "Nova poética" (de Belo belo, 1948), de Bandeira - a quem Drummond dedica o poema! -, na imagem da lama: “(...) Sai um sujeito de casa com a roupa de brim branco muito bem engomada, e na primeira esquina passa um caminhão, salpica-lhe o paletó ou a calça de uma nódoa de lama: // É a vida. (...)” (BANDEIRA, 1993, p. 188). Brasília, veremos, é metonímia e metáfora do Brasil (embora o poeta, em sua utopia, tenha criado - no espaço poético, diria Blanchot, espaço em que tudo é possível - sua mítica Braxília). Estávamos em 1979, ano que se inicia com a revogação do AI-5 em 31/12/1978.

O segundo poema de Nicolas Behr, presente na antologia Laranja seleta, e que também protagoniza uma ação intertextual, seqüestrando Drummond, tem "Drummond brasiliensis" como título e diz:

brasília, e agora?

com o avião na pista quer levantar vôo não existe vôo quer se afogar no paranoá mas o lago secou quer falar com o presidente mas este viajou 
quer se esconder no cerrado o cerrado acabou quer ir pra goiás goiás não há mais

e agora, brasília?

(BEHR, 2007, p. 96)

Este poema, publicado originalmente em Beijo de hiena, de 1993, foi buscar, mais uma vez, uma clássica matriz drummondiana: "José”, do livro homônimo de 1942. Com o mundo em guerra e o Brasil em pesado clima ditatorial, a desesperança toma conta do outrora debochado poeta modernista, sob a capa, agora, de um José que mal esconde o Carlos que se espalha ao longo da obra drummondiana: "o bonde não veio, / o riso não veio, / não veio a utopia / e tudo acabou" - as redondilhas menores, em tom menor, sintetizam o sentimento reinante de amargura e inércia.

Das seis estrofes de "José", o poema de Behr vai se aproximar mais estreitamente da quarta, que se transcreve para a comparação:

Com a chave na mão quer abrir a porta, não existe porta; quer morrer no mar, mas o mar secou; quer ir para Minas, Minas não há mais. José, e agora?

(ANDRADE, 2006, p. 107)

No poema de Behr, o José de Drummond vira Brasília, antropomorfizada, em situação aparentemente tão aporética quanto à do personagem de Carlos: há chave e avião, mas não tem porta nem voo; para morrerem, há mar e lago, mas ambos secaram; para a fuga, há Minas e Goiás, mas o tempo aboliu essa possibilidade de volta ao passado. Aqui, numa espécie de licença poética autobiográfica, à Minas de origem do 
poeta modernista, o poeta marginal inventa para si (para o eu lírico que fala) uma falsa origem, Goiás, em vez de Mato Grosso, seu estado natal, muito provavelmente agindo "por amor à rima" $\underline{5}$ : goiás / goiás / mais. Recorde-se, igualmente, que o território de Brasília, distrito federal, está encravado no estado de Goiás, daí a impossibilidade de querer ir para um "goiás" que não há mais, um Goiás de antes da invenção de Brasília por JK.

De modo ambíguo, o sujeito que dá título ao poema, "Drummond brasiliensis", é também o sujeito que nele se expõe, misturando-se ao outro "sujeito", Brasília, que substitui sintática e semanticamente o personagem drummondiano, José. O poema de Behr, qual o de Drummond, se sustenta em base anafórica: aquilo que se quer não se pode mais ter, embora, lembrando o mítico suplício de Tântalo, tudo esteja de algum modo próximo.

O drama de Drummond, ainda que possa ser estendido a toda uma geração e a um período, se dá a ver - porque assim o quis - pelo viés de um sujeito: um sujeito comum, sim, “que é sem nome”, um josé, um zé, mas também um sujeito singularizado, com "biblioteca", "lavra de ouro", de "Minas". Ao ativar o recurso da intertextualidade, e ultrapassando o mero jogo paródico, Nicolas Behr recorda a história que dá chão àquele poema, a década da segunda grande guerra mundial, para mostrar que na capital do Brasil há um sentimento finissecular de perda, de inércia, de falta. A transposição, para usar termo de Kristeva, de José em Brasília indica de imediato a vontade de dar ao desamparo individual uma feição mais coletiva, social, política.

Theodor Adorno em "O artista como representante" (2003) desenvolve reflexões que retomaria anos depois em artigo mais conhecido - "Palestra sobre lírica e sociedade" (1957). Naquele texto, Adorno se dispõe a mostrar, na contracorrente da opinião vigente, o "conteúdo histórico e social inerente à obra de Valéry" (p. 152), a partir da análise do livro Degas, dança desenho, do poeta-crítico francês. Para este, segundo o filósofo alemão, "o homem como um todo, e toda a humanidade, estão presentes em cada expressão artística e em cada conhecimento científico” (p. 155). Tal concepção se fundamenta na idéia de "homem completo", ou seja, aquele que investe todas as faculdades na realização dos atos, assim como aquele que quer compreender 
estes atos. Para Valéry, "Flaubert e Mallarmé são exemplos literários da consagração total de uma vida à exigência total imaginária, que eles confiavam à arte da pena" (p. 158). O homem, portanto, ao dar o máximo de si estaria não só satisfazendo a exigência da própria arte, mas elevando-se a si mesmo, ao colocar a razão - lógica, coerência, concentração, densidade, resistência, organização (p. 163) - em posto privilegiado no ato criador, desvencilhando-se, assim, da arte fácil: "não se tornar estúpido, não se deixar enganar, não ser cúmplice: estes são os modos de comportamento social sedimentados na obra de Valéry, uma obra que recusa o jogo da falsa humanidade, da aprovação social à humilhação do homem" (p. 163). O homem completo, o artista completo seriam, então, mais do que um indivíduo que produz uma obra qualquer, o representante do "sujeito social coletivo" (p. 164); mais do que o criador de algo contingente, dispensável, o fundador de alguma coisa incontornável, única porque histórica, porque - sempre com o propósito apriorístico da grandeza máxima da completude artística - encontrou a forma extrema, exata, de sua existência. $\mathrm{O}$ esplendor do homem que cria está todo investido exatamente naquilo que cria: a grandeza de um diz da grandeza do outro, o que um homem podeé porque o seu tempo pôde. Neste texto, Adorno não discute se Valéry e Nietzsche superestimaram a arte, dando-lhe um lugar metafísico, e daí longe da história. Interessa a ele desvincular a criação artística da "sina da cega individuação" (p. 164), tributária de heranças românticas, que erigiram estátuas à figura semidivina do gênio.

Há na poesia de Nicolas Behr um empenho de falar para muitos e por muitos. Para lembrar termos leminskianos, o relaxo de seus versos é constituinte do próprio capricho que alcança na fatura final da forma que lhe é possível. Grande parte de seu engenho vem dessa vontade de atribuir à arte uma responsabilidade social, e grande parte dessa vontade se realiza por intermédio da adoção de um locus coletivo: a cidade de Brasília (não mais o quarto e a casa, espaços tão queridos dos marginais) (MEDEIROS, 1998). E a cidade de Brasília não é uma cidade qualquer: ela é símbolo, ela representa uma instância de poder, uma história complexa de interesses políticos, de criação de heróis e mártires, de emblemáticos arquitetos e folclorizados candangos. Pensar em Brasília é pensar no Brasil. Eis que em recentíssimo livro, Iniciação à dendrolatria, de 2006, com poemas já 
incluídos emLaranja seleta, de 2007, Nicolas Behr vai buscar de novo a inspiração em Drummond para seu ecológico poema-paródia:

quando eu nasci uma árvore torta

dessas que vivem no cerrado

chegou pra mim

e não disse nada

não havia nada a dizer

não havia nada a salvar.

(BEHR, 2007, p. 118)

A memória poética brasileira tem, sem dúvida, no "Poema de sete faces", um de seus pilares mais fortes: é o primeiro poema do primeiro livro do primo-poeta Carlos Drummond de Andrade, tendo sido todas as sete estrofes reviradas de ponta-cabeça pela crítica literária especializada e tendo sido glosado às pencas por artistas de distintos matizes, demonstrando sua força de irradiação, força que provoca, proporcionalmente, desejos parricidas violentos. Behr glosa somente a estrofe inicial: "Quando nasci, um anjo torto / desses que vivem na sombra / disse: Vai, Carlos! ser gauche na vida." (ANDRADE, 2006, p. 5). Aqui, mais uma vez, o procedimento intertextual vai se efetivar numa troca de sinal: a problemática de um indivíduo dá lugar a uma questão coletiva, ainda que de forma sutil, sem barulhos. Embora em ambos se mantenha um “eu”, lírico e gaiato, encenando mesmo um bom humor, o desfecho da estrofe é diverso: em Drummond, o anjo se refere com intimidade ao poeta Carlos (a despeito da máscara que o sujeito lírico pressupõe, o fato é que a escolha onomástica - "Carlos" - aponta uma vontade de identificação entre este sujeito e o sujeito autoral), profetizando-lhe um futuro gauche, marginal; em Behr, a árvore quebra a expectativa (estando no lugar que, no texto anterior, cabia ao anjo) e simplesmente não diz nada.

O cerrado, lembremos, se situa geralmente em terreno plano, tem prolongados períodos de seca - é vegetação típica do planalto central do país - de Brasília. O anjo 
"torto" de Drummond vive na sombra, se parece com o poeta ao qual se dirige, é figura espiritual, metaforizada, mediando a relação entre homem e deus; a árvore "torta" de Nicolas vive em lugar árido e seco, é "torta" literalmente, é real e carrega resignação: não diz nada, seria infrutífero e retórico se dissesse algo. O humor seca. Em excelente estudo sobre a poesia de Behr, Gilda Furiati afirma: “A denúncia contra a destruição ou a exploração do cerrado nativo em troca de plantação de soja também se tornará uma linha explorada pelo poeta, anos mais tarde, com a publicação do livroIniciação à Dendrolatria, publicado em 2006 e todo dedicado às árvores e à preservação ambiental" (2007, p. 38). Dendrolatria significa respeito e adoração pelas árvores.

O jovem Drummond, de 1930, ano de Alguma poesia (onde está o "Poema de sete faces"), não tinha então trinta anos; o alternativo Nicolas, em 2006, ano de Iniciação à Dendrolatria (onde está o poema em foco da "árvore torta"), já chegava aos cinquenta anos, maduro e ainda maldito. Sob essa perspectiva temporal, o velho e gauche Nicolas lê o novo e comportado Drummond, que "Quase não conversa. / Tem poucos, raros amigos".

Em um quarto poema de Laranja seleta, o também familiar "O enterrado vivo", deFazendeiro do ar (1954), de Drummond, é apropriado por Behr, em poema publicado originalmente em Peregrino do estranho (2004, grifos abaixo meus):

É sempre no passado aquele orgasmo, é sempre no presente aquele duplo, é sempre no futuro aquele pânico.

É sempre no meu peito aquela garra. É sempre no meu tédio aquele aceno. É sempre no meu sono aquela guerra.

É sempre no meu trato o amplo distrato. Sempre na minha firma a antiga fúria. Sempre no mesmo engano outro retrato.

É sempre nos meus pulos o limite.

É sempre nos meus lábios a estampilha. É sempre no meu não aquele trauma. é sempre dentro de mim esse muro as divisórias internas do escritório carnal quem me cobra o fracasso? quem? me iludo e digo que no meu passado vive um menino feliz (menino sem mimo) o tempo e esse desgaste, esse vento áspero é sempre este poema a me fitar no escuro essas fraturas expostas, essas carnes podres em tudo, a presença viva da poesia de drummond é sempre dentro de mim essa vontade enorme de caminhar entre as gentes e encontrar pessoas ah, esse desprezo, essa inveja, essa alegria covarde dentro de mim, fora de mim, as armaduras de aço os escudos, as couraças, o museu do toque a promessa de mais uma linha, conclusiva, 
Sempre no meu amor a noite rompe. Sempre dentro de mim meu inimigo. E sempre no meu sempre a mesma ausência. final

a tensão que dignifica a vida esse mal-estar permanente o sofrimento: meu e alheio as testas enrugadas, os braços cortados

(ANDRADE, 2006, p. 404) o coração aberto, coberto de moscas o poema-lixa polindo os olhos um ipê roxo florido lá longe, no meio da mata é sempre dentro de mim esse reciclar de lágrimas

é sempre dentro de mim esse vazio

(BEHR, 2007, p. 125)

Este último exemplo de apropriação repete um procedimento intertextual já explicitado, e, vemos, recorrente: onde, em Drummond (isto é: nos poemas de Drummond escolhidos), impera a plena subjetividade, sem disfarce, na tensão entre eu e mundo (SANT'ANNA, 1980), em Nicolas Behr se impõe um desejo de troca, de reciprocidade, de participação, "essa vontade enorme / de caminhar entre as gentes e encontrar pessoas". Um verso de Behr resume bem a diferença de postura: "o sofrimento: meu e alheio". Os belíssimos decassílabos de Drummond se apoiam em anáforas e imagens provocantemente herméticas; os versos brancos e livres de Behr mantêm o eco - é sempre, é sempre - do poema primeiro, mas as imagens se querem diretas, referenciais, selvagens, transparentes.

O autor de Claro enigma é o mestre, não há dúvida, do poeta de Brasília. Não bastasse, "em tudo, a presença viva / da poesia de Drummond", aparecendo aqui e ali e acolá na obra de Behr, a confissão se faz categórica numa entrevista:

Drummond é meu ídolo. A pessoa e a obra de Drummond caminharam juntos. O que me fascina na poesia dele é porque, além da imensa qualidade, é extremamente acessível, fácil mesmo. Gosto da aspereza da poesia dele, daquele mal-estar permanente. $\mathrm{E}$, na vida, ele não cagou regras, não virou medalhão nem acadêmico, não precisou de nenhum balangandã para ser poeta. Mas eu evito ler muito Drummond porque minha poesia fica pequenininha, me sinto diminuído. Aí, eu paro. Por isso, quando alguém fala "você é muito influenciado por Drummond!', eu respondo: "Graças a Deus, imagina se fosse por Olavo Bilac!” (MARCELO, 2004, p. 49)ㅁ․ 
Entende-se, comumente, que o recurso da intertextualidade se associa a categorias como influência e subversão, gosto e erudição: há o desejo de se filiar a uma legitimada e legitimante genealogia e (quase) ao mesmo tempo de transgredir esta filiação. Nicolas Behr faz questão de mostrar seu gosto por Drummond: escolhe poemas conhecidos, cita-o como ídolo-mor, destaca nele o que ele, filho e idólatra, quer e crê ter: qualidade, acessibilidade, aspereza, liberdade, rebeldia, marginalidade. Todavia, o gesto parricida é inevitável para a sobrevivência: o filho deve ir aonde o pai não foi. (Ou, isto é o que importa, lá aonde eu afirmo que o pai não chegou.) Para que não precise pedir perdão pela covardia - "Sou o que não foi, o que vai ficar calado" (ROSA, 1988, p. 37) -, o poeta ousa, invade, rebela-se, e diz um amoroso e sonoro não ao nome do pai.

Para Harold Bloom, o "sublime, na poesia, é sempre o ponto da citação: da citação sublimada" (1991, p. 14), conquanto sua teoria da influência não seja uma teoria da alusãotampouco de causação. Bloom cria seis razões revisionárias para detectar o movimento da influência:clinamen, tessera, kenosis, demonização, askesis e apophrades. Deste "curioso bailado de figuras", na irônica expressão de Laurent Jenny $(1979$, p. 8), parece que o movimento levado a cabo por Nicolas Behr foi o da tessera, que consiste num jogo de complementação e antítese: o poema segundo preserva os termos do primeiro, mas altera-lhes o significado, como se o precursor não tivesse ido longe o bastante. Téssera, desde o latim tessera, é exatamente isto: uma tabuinha que, na Roma antiga, servia como uma espécie de senha. Foi o que Nicolas fez, basicamente, ao retomar os poemas de Drummond: ainda que sob o signo do exagero, podemos dizer que a poesia de Drummond foi e é a "presença viva", uma senha que Nicolas Behr elaborou para adentrar, a seu modo, a poesia brasileira. O Brasil e as Minas Gerais que Drummond pensa em seus versos retornaram em forma de Braxília, que é Brasília reinventada, sua Pasárgada, sua cidade visível (para lembrar o livro clássico de Calvino).

Não há como entender a obra de Behr sem atentar para este fenômeno de construção de uma utopia através da arte, em particular, da arte poética. E atentos estão aqueles que dela se avizinham: além do referido estudo de Gilda Furiati, destaquem-se também as pesquisas de Tiago Borges dos Santos (2008), de Laíse Ribas Bastos (2009) 
e de Francisco Kaq (2009) 7 e, ainda, a edição já referida do livro Nicolas Behr - eu engoli Brasília, de Carlos Marcelo. Em todos, a onipresença da capital do país na poesia do autor de Brasiléia desvairada (e de Porque construí Braxília, Poesia Pau-Brasília, Braxília revisitada e Brasilíada) é mote incontornável para a reflexão crítica.

Num dos aforismos de Minima moralia [1951], intitulado "De gustibus est disputandum" [1944], Adorno afirma que toda obra de arte, porque sempre cotejada com seus pares, quer "levar a morte a todas as outras" (2001, p. 73). Na verdade, o discurso da "incomparabilidade das obras de arte" camufla, para o filósofo, o desejo de “aniquilar-se umas às outras" (p. 73). Mais ainda: a obra de arte quer tudo, quer o seu próprio fim, superando, dessa maneira, a própria possibilidade de comparação. Esta vigorosa metáfora adorniana da arte - seja pelo gesto corriqueiro da comparação, seja pelo movimento agônico da destruição do outro ou mesmo da autodestruição como ápice da própria força - aponta para uma idéia, uma abstração, uma reflexão que, embora no plano concreto não ganhe correspondência prática (nem careça), leva longe o pensamento teórico sobre o mundo artístico, aqui distante de qualquer tom cordial.

Nicolas Behr se apropria, sem pudores, da poesia drummondiana, ou seja, da poesia mais reconhecida e legitimada do país, com o intuito (mesmo não programático nem consciente) de sinalizar para uma radical diferença: o poeta mineiro atravessou décadas de Brasil, do início do século a 1987, quando falece, e seus versos testemunham, livro a livro, a passagem da história nacional e mundial pelo imaginário de um sujeito preocupado, sim, com as coisas, mas extremamente ensimesmado; o poeta cuiabano, desde 1977 e seu Iogurte com farinha, vem criando uma persona lírica irreverente e alternativa, com um grau altíssimo de comprometimento social, a ponto de fundar, livros a fio, uma cidade - Braxília - não somente para si, mas para todos aqueles que, adaptando frase memorável de Marx e Engels, querem interpretar o mundo etransformá-lo.

Como quem não quer nada, com sua poesia fast-food e fácil, Behr lança mão do recurso da intertextualidade não para fazer brilhar em seu texto o texto do cânone Drummond e assim angariar um capital simbólico para se manter na tribo. Talvez seja isto também. Mas, sobretudo, o poeta braxiliense quer nos fazer ver que qualquer 
modelo, mesmo o maior modelo, deve ser abalado, abalado por dentro, daí o engenho de reescrever o Brasil de um cético e inerte Drummond (porque há mais de sete faces) num outro Brasil de um militante poeta pelejador.

Fique claro: nem entendo ter a poesia de Drummond um tom hegemonicamente alienado, dócil, conformista (o que seria ignorar a vastidão de seu projeto poéticopensante) (DALVI, 2009), nem tampouco considero a poesia de Behr um exemplo clássico de rebeldia, engajamento, testemunho. Afirmo, e repito, que a apropriação dos quatro poemas de Drummond, explicitamente citados em Laranja seleta, se faz de forma interessada, com visível mudança da perspectiva ideológica (se a mudança é inevitável, porque a história atua na mentalidade dos homens, a perspectiva é imprevisível, porque cada homem se constitui como cidadão político a partir de forças múltiplas, absolutamente indomesticáveis).

O Brasil de Nicolas Behr se ergue sob a sombra da tradição, mas agora ganha novo rumo: não repete o refrão, não repete o estilo, não repete as idéias. Alimenta-se de tudo isto que vem do amigo, mas, feito um ímã que gira em torno do campo gravitacional, resiste a colar um polo noutro.

O ilustre "poeta federal" vira "um poeta de uma cidade-satélite qualquer"; o entediado e metafísico José se transforma numa problemática e coletiva Brasília; o etéreo anjo torto que vive na sombra se reconfigura na concreta árvore torta que vive no cerrado; e o revoltado, mas retórico, "enterrado vivo" dá lugar a um sujeito com uma "vontade enorme / de caminhar entre as gentes e encontrar pessoas". Mais que jogo, exibição ou disputa, a intertextualidade funciona como arma para matar o pai que se ama, pois o que ele diz e o modo como diz já são passado. Tanto quanto o Brasil, o tempo é a matéria de ambos - mas já não concordam em nada. $\mathrm{O}$ vasto mundo de Carlos não cabe na cidade do outro, do filho prófugo. Ímãs, no entanto, não podem mais ir de mãos dadas. Não há saída: tão-somente desmentir o pai, sempre, para sempre encantoado.

\section{Referências}


ADORNO, Th. O artista como representante [1953]. Notas de literatura I. Tradução e apresentação: Jorge M. B. de Almeida. São Paulo: Duas Cidades; Ed. 34, 2003. p. 151164.

ADORNO, Th. Minima moralia. Tradução: Artur Morão. Lisboa: Edições 70, 2001.

ANDRADE, C. D. de. Antologia poética. 63.ed. Rio de Janeiro: Record, 2009.

ANDRADE, C. D. de. Poesia completa. Rio de Janeiro: Nova Aguilar, 2006.

BANDEIRA, M. Estrela da vida inteira. Rio de Janeiro: Nova Fronteira, 1993. p. 188.

BARBOSA, J. A. Alguma crítica. Cotia, SP: Ateliê, 2002.

BASTOS, L. R. Nicolas Behr: um (anti)dizer poético. Disponível emhttp://www.abralic.org.br/enc2007/anais/50/507.pdf. Acesso em 27 junho 2009.

BEHR, N. Entrevista. In: MARCELO, C. Nicolas Behr - eu engoli Brasília. Brasília: Ed. do Autor, 2004, p. 45-57.

BEHR, N. Laranja seleta. Rio de Janeiro: Língua geral, 2007.

Restos vitais. Brasília: Ed. do Autor, 2005.

Umbigo. Brasília: LGE, 2006.

BLOOM, H. A angústia da influência - uma teoria da poesia. Tradução e apresentação: Arthur Nestrovski. Rio de Janeiro: Imago, 1991.

O cânone ocidental: os livros e a escola do tempo. Tradução: Marcos Santarrita. Rio de Janeiro: Objetiva, 1995.

DALVI, M. A. Drummond, do corpo ao corpus: O amor natural toma parte no projeto poético-pensante. Vitória: Edufes, 2009.

FREITAS FILHO, A. Raro mar. São Paulo: Companhia das Letras, 2006.

FURIATI, G. Brasília na poesia de Nicolas Behr: idealização, utopia e crítica.

Dissertação. Brasília, DF: UnB, 2007.

JENNY, L. A estratégia da forma. Poétique 27 - Intertextualidades. Tradução: Clara Crabbé Rocha. Coimbra: Livraria Almedina, 1979, p. 5-49.

KAQ, F. As cidades de Nicolas Behr. Disponível em http://www.nicolasbehr.com.br/pagartigos.htm. Acesso em 27 junho 2009.

KRISTEVA, J. Introdução à Semanálise. Tradução: Lucia Helena Franco Ferraz. São Paulo: Perspectiva, 1974.

LEMINSKI, P. Distraídos venceremos. São Paulo: Brasiliense, 1987.

MARCELO, C. Nicolas Behr - eu engoli Brasília. Brasília: Ed. do Autor, 2004.

MEDEIROS, F. T. de. Play it again, marginais. In: PEDROSA, C.; MATOS, C.; NASCIMENTO, E. (Org.). Poesia hoje. Niterói: EdUFF, 1998, p. 53-69.

MORICONI, I. Como e por que ler a poesia brasileira do século XX. Rio de Janeiro: Objetiva, 2002.

ROSA, G. Primeiras estórias. Rio de Janeiro: Nova Fronteira, 1988. 
SANT'ANNA, A. R. de. Carlos Drummond de Andrade: análise da obra. 3.ed. Rio de Janeiro: Nova Fronteira, 1980.

SANTIAGO, S. O intelectual modernista revisitado. In: . Nas malhas da letra.

São Paulo: Companhia das Letras, 1989, p. 165-175.

SANTOS, T. B. dos. Lira pau-Brasília: entre fardas e superquadras: poesia, contracultura e ditadura na Capital (1968-1981). Dissertação (Mestrado). UnB, Brasília, DF, 2008.

1 Programa de Pós-Graduação em Letras, Universidade Federal do Espírito Santo (UFES), CEP: 29075-910, Vitória, ES, Brasil. E-mail: wilberthcfs @gmail.com. Este artigo se vincula à pesquisa que desenvolvo junto ao CNPq com o título "Poesia e testemunho: humor e dor no Brasil - de 1964 ao contemporâneo".

2 Pau-Brasília Viveiro Eco-Loja em http://www.paubrasilia.com.br/ e também http://www.nicolasbehr.com.br/

3 Polêmicas à parte, registre-se que na lista de 850 autores de $O$ cânone ocidental, do citado Bloom (1995), só um brasileiro comparece: exatamente ele, Drummond. Ademais, para Italo Moriconi, em Como e por que ler a poesia brasileira (2002), o poema brasileiro do século XX é "A máquina do mundo", o livro é Claro enigma. Logo, Moriconi parece concordar com verso de Armando Freitas Filho, em Raro mar (2006): "Drummond é o cara".

4 Silviano Santiago vem estudando, com lucidez, ao longo de sua obra ensaística, as relações delicadas e perigosas entre o intelectual e o Estado brasileiros. Veja-se, por exemplo, "O intelectual modernista revisitado", em Nas malhas da letra (1989).

$\underline{5}$ Cito verso final do poema "O teixugo estético", de Christian Morgenstern, em tradução de Haroldo de Campos: "Um teixugo / sentou-se num sabugo / no meio do refugo /// Por que / afinal? /// O lunático / segredou-me / estático: /// O re- / finado animal / acima / agiu por amor à rima." (apud: BARBOSA, 2002,p. 320).

6 Em Umbigo (BEHR, 2006), dirá: "minha poesia tem inveja da poesia de drummond" (p. 9), "minha poesia tropeça na pedra que drummond colocou no meio do caminho" (p. 11) etc.

7 Aqui, por exemplo, lemos: "Braxília é não só imaginária, mas feita à medida do poeta: em sua grafia (como na pronúncia) já se inscreve a marca de singularidade pessoal. (...) Braxília é a utopia pessoal do poeta que amadureceu. Mas não deixa de manter tensões e atritos com a cidade real; até porque esta se tornou uma realidade mais dura, problemática e indiferente (mesmo sem ditadura)". 
